Morikawa A, Kuroume T. Bronchial hyperresponsiveness in younger children with asthma. Ann Allergy 1988;60: 103-6.

9 Yan K, Salome C, Woolcock AJ. Rapid method for measurement of bronchial responsiveness. Thorax 1983 38:760-5.

10 Chatham M, Bleecker ER, Norman P, Smith PL, Mason P. A screening test for airways reactivity-an abbreviated methacholine inhalation challenge. Chest 1982;82:15-8.

11 Cockcroft DW, Killian DN, Mellon JJA, Hargreave FE. Bronchial reactivity to inhaled histamine: a method and clinical survey. Clin Allergy 1977;7:235-43.

12 Polgar G, Promadhat V. Pulmonary function testing in children: techniques and standards. Philadelphia, London, Toronto: WB Saunders Co, 1971.

13 Altman DG, Bland JM. Measurement in medicine: the analysis of methods comparison studies. The Statistician 1983;32:307-17.

14 Fleiss JL. The design and analysis of clinical experiments. New York. John Wiley \& Sons, 1986:1-14.

15 Bland MJ, Altman DG. Statistical methods for assessing agreement between two methods of clinical measurement. Lancet 1986; i:307-10.

16 Chinn S. Repeatability and method comparison. Thorax $1991 ; 46: 454-6$.
17 Cockcroft DW, Berscheid BA, Murdock KY. Measurement of responsiveness to inhaled histamine using FEV : com parison of $\mathrm{PC}_{20}$ and threshold. Thorax 1983;38:523-6.

18 Ryan G, Dolovich MB, Roberts RS, Frith PA, Juniper EF, Hargreave FE, et al. Standardization of inhalation provocation tests: two techniques of aerosol generation and inhalation compared. Am Rev Respir Dis 1981;123. 195-9.

19 Juniper EF, Frith PA, Dunnett C, Cockcroft DW, Hargreave FE. Reproducibility and comparison of responses to inhaled histamine and methacholine. Thorax ponses to inhaled

20 SEPCR Working Group 'Bronchial Hyperreactivity'. Eds Eiser NM, Kerrebijn KF, Quanjer PH. Guidelines fo standardization of bronchial challenges with (non-specific) bronchoconstricting agents. Bull Eur Physiopathol Respir 1983;19:495-514

21 Duiverman EJ, Neijens HJ, Van Strik R, Van Der Snee-Van Smaalen M, Kerrebijn KF. Bronchial responsiveness in asthmatic children aged 3 to 8 years measured by forced pseudo-random noise oscillometry. Bull Eur Physiopathol Respir 1986;22:27-34.

22 Wilson NM, Phagoo SB, Silverman M. Atopy, bronchia responsiveness and symptoms in 3 year old wheezy children. Arch Dis Child 1992;67:491-5.

\title{
Adventitia
}

\section{Every dogma has its day}

When I went to Baltimore, Maryland, in 1958 , to supplement my meagre salary I worked in the Baltimore city health department tuberculosis clinics. At that time, depending on their colour, those who developed tuberculosis were confined to one or other of two monolithic goals. If they were lucky they would emerge after some mutilative surgical procedure two or three years later. Refusal to undergo treatment resulted in a court order and almost certain confinement. When the owner of the premier Chinese restaurant in Baltimore developed tuberculosis one of the more important issues before the city council was to decide whether he would be admitted to the black or the white sanatorium. As a successful entrepreneur, he received special dispensation and was admitted to the white facility.

About that time the British and Indian Medical Research Councils published the results of the Madras study showing that tuberculosis could be treated as effectively at home as in hospital, and that once chemotherapy had been started, and despite persistently positive sputum, the patient lost his infectiousness within a few days. The study was dismissed with scorn by most of the tuberculosis establishment in the United States. It was about that time that I had the good fortune to come into contact with $\mathrm{Dr}$ Richard Riley, who at that time was head of the department of environmental medicine at the Johns Hopkins Medical School. His name was known to me as the originator of the method for measuring the diffusing capacity for oxygen and for his seminal work on ventilation-perfusion relationships while he was at Bellevue Hospital. A self effacing and modest man, Dick Riley, in the opinion of many, had been the major driving force in the laboratory of Cournand and Richards. He had a tremendous and justified reputation as a respiratory physiologist, but few at that time knew that he had been working for several years with the late Professor Wells on the infectiousness of tuberculosis and had been conducting a series of most ingenious experiments at Loch Raven Veterans Administration Hospital. The ventilation system there had been modified so that air could be extracted from a series of single wards in which were housed patients with tuberculosis, some of whom were undergoing treatment while others had not yet started treatment. In a few rooms patients with acquired drug resistance were housed. The extracted air was carried by a series of vents to several chambers containing guinea pigs and then vented to the outside. These studies showed irrevocably the lack of infectiousness of patients once they had started chemotherapy, the sterilising effect of ultraviolet light on droplet nuclei containing tubercle bacilli, and much else besides. Few contemporary physicians realised the contribution Dick Riley made to the termination of the gaol sentences that were part and parcel of the treatment in Maryland and elsewhere in the United States, and still fewer were aware that he himself had been successfully treated for tuberculosis.

WKC MORGAN 